\title{
Lanthanide(III) Complexes with Tridentate Schiff Base Ligand, Antioxidant Activity and X-Ray Crystal Structures of the Nd(III) and Sm(III) Complexes
}

\author{
Mbossé Ndiaye Gueye ${ }^{\mathrm{a}}$, Moussa Dieng ${ }^{\mathrm{a}}$, Ibrahima Elhadji Thiam ${ }^{\mathrm{a}}$, Djiby Lo ${ }^{\mathrm{a}}$, \\ Aliou Hamady Barry ${ }^{b}$, Mohamed Gaye ${ }^{a, *}$ and Pascal Retailleau ${ }^{c}$ \\ ${ }^{a}$ Department of Chemistry, University Cheikh Anta Diop, Dakar, Sénégal. \\ ${ }^{b}$ Department of Chemistry, University of Nouakchott, Mauritania. \\ 'Centre de Recherche de Gif, Institut de Chimie des Substances Naturelles, CNRS-UPR2301, \\ 1 Avenue la Terrasse, 91198 Gif sur Yvette, France.
}

Received 13 September 2016, revised 7 November 2016, accepted 24 November 2016

\begin{abstract}
The tridentate $\mathrm{N}_{4}$-type Schiff base was synthesized from the condensation reaction of 2-hydrazinopyridine and pyridine-2-carbaldehyde. Neodymium and Samarium complexes were isolated when the corresponding nitrate salt was added to the solution of the ligand. The isolated compounds were characterized by elemental analyses, IR study, room temperature magnetic measurements and single X-ray crystal diffraction of the two crystals. Both complexes crystallize in the monoclinic system with space group $P 21 / c$. The cell parameters of the Nd complex are $a=11.0927(8) \AA ⿻$, b = 17.9926 (13) $\AA$, c = 11.9395(9) $\AA$ and $\beta=115.274(5){ }^{\circ}$ while the Sm complex shows parameters cell of $a=11.0477(8) \AA, b=17.9254(13) \AA, c=11.9149(8) \AA$ and $\beta=115.489(5)^{\circ}$. The $\mathrm{X}$-ray study reveals isotopic $\mathrm{Nd} / \mathrm{Sm}$ binuclear structures were each metal ion is nine-coordinated in the same fashion. Both metal centers have distorted tricapped trigonal prism geometry, with the Schiff base acting as tridentate ligand. The $\mathrm{DPPH}^{\bullet}$ radical scavenging effects of the Schiff base ligand and its $\mathrm{Ln}$ (III) complexes were screened. The Ln(III) complexes were significantly more efficient in quenching $\mathrm{DPPH}^{\bullet}$ than the free Schiff base ligand.
\end{abstract}

KEYWORDS

Lanthanide complexes, hydrazino, antioxidant activity, X-ray structure.

\section{Introduction}

In the past decade, the lanthanide coordination chemistry was one of the most focused areas of research. ${ }^{1-3}$ The intriguing structures $^{4-6}$ and the potential uses in a wide variety of areas as diagnostic tools in biology ${ }^{7}$ catalysis, ${ }^{8}$ luminescence ${ }^{9}$ and magnetism ${ }^{10}$ reinforce the interest of chemists in these areas of research. A few years ago our research group initiated a project concerning rare earth metal chemistry ${ }^{11}$ in a search for unusual molecular materials. ${ }^{12}$ By use of an acyclic Schiff's base in presence of acetate groups, it is possible to introduce two identical or different lanthanide ions and to study their physicochemical properties. ${ }^{13,14}$ The flexibility and the multiple coordination site of the acyclic ligand provides several possible structure with lanthanide ions. ${ }^{15,16}$ The carboxylate groups can adopt various coordination modes, which may cause the generation of novel structures. ${ }^{17,18}$ Hydrazones are Schiff base precursors with a triatomic moiety connection of $-\mathrm{C}=\mathrm{N}-\mathrm{NH}-$. They are widely used in the synthesis of complexes to generate original structures. ${ }^{19,20}$ Coordination compounds from this type of ligand have a variety of applications. Many results concerning their antibacterial, ${ }^{21}$ antifungal, ${ }^{22}$ anticancer ${ }^{23}$ and antidepressant ${ }^{24}$ activities have been described in the literature. This report presents the synthesis, characterization, and X-ray structures of neodymium(III) and samarium(III) complexes derived from 1(pyrydin-2yl)-2-(pyridine-2-ylmethylene)hydrazine (HL). HL is an acyclic hydrazine ligand bearing nitrogen donors containing

*To whom correspondence should be addressed.E-mail:mohamedl.gaye@ ucad.edu.sn one coordination cavity which can encapsulate large ions such as lanthanides.

\section{Materials and Procedures}

2-Hydrazinopyridine, 2-pyridinecarbaldehyde and the lanthanide nitrate salts were commercial products (from Alfa and Aldrich) and were used without further purification. Solvents were of reagent grade and were purified by the usual methods. The analyses for carbon, hydrogen and nitrogen were carried out using a LECO CHNS-932 instrument. ${ }^{1} \mathrm{H}$ and ${ }^{13} \mathrm{C}$ spectra of the compounds were recorded in DMSO- $\mathrm{d}_{6}$ with TMS as internal reference on a Bruker Advance operating at $250 \mathrm{MHz}$. The IR spectra were recorded as $\mathrm{KBr}$ discs on a Bruker IFS-66 V spectrophotometer $\left(4000-400 \mathrm{~cm}^{-1}\right)$. The molar conductance of $10^{-3} \mathrm{M}$ solutions of the metal complexes in methanol were measured at $25^{\circ} \mathrm{C}$ using a WTW LF-330 conductivity meter with a WTW conductivity cell. Room temperature magnetic susceptibilities of the powdered samples $\left\{\right.$ calibrant $\left.\mathrm{Hg}\left[\mathrm{Co}(\mathrm{SCN})_{4}\right]\right\}$ were measured using a Johnson Matthey scientific magnetic susceptibility balance.

\subsection{Preparation of the Ligand $\mathrm{HL}$}

2-Hydrazinopyridine $(1.0913 \mathrm{~g}, 10 \mathrm{mmol})$ in $20 \mathrm{~mL}$ of ethanol was added to a solution of 2-pyridinecarbaldehyde (1.0711 g, $10 \mathrm{mmol}$ ) dissolved in $25 \mathrm{~mL}$ of ethanol. The resulting mixture was stirred under reflux during $30 \mathrm{~min}$. After cooling, the volume was completed to $100 \mathrm{~mL}$ with ethanol and stored in the refrigerator. $10 \mathrm{~mL}$ of this solution was evaporated to dryness and the 
NMR spectrum of the resulting liquid was recorded. $\delta_{\mathrm{H}}(250 \mathrm{MHz}$, DMSO-d $)_{6}$ : 11.185(1H,s, H-N-N); 8.542(1H, d, J 4.75 Hz, H-Py); 8,159(1H, d, J 1.75 Hz, H-Py); 8.144(1H, s, H-C =N); 7.972(1H, d, J $7.75 \mathrm{~Hz}, \mathrm{H}-\mathrm{Py}) ; 7.823(1 \mathrm{H}, \mathrm{dd}, J 1.75$ and $7.5 \mathrm{~Hz}, \mathrm{H}-\mathrm{Py}) ; 7.766(1 \mathrm{H}$, mult, H-Py); 7.313(2H, d, J 7.75 Hz, H-Py); 6.820(1H, dd, J 4.75 and $7.25 \mathrm{~Hz}, \mathrm{H}-\mathrm{Py}) . \delta_{\mathrm{C}}\left(250 \mathrm{MHz}, \mathrm{DMSO}-\mathrm{d}_{6}\right): 106.500$ (C-8), 115.528 (C-10), 118.810 (C-4), 122.878 (C-2), 136.422 (C-3), 137.989 (C-9), 139.164 (C-6), 147.798 (C-11), 149.180 (C-1), 154.257 (C-7), 156.660 (C-5).

\subsection{Preparation of the Complexes}

To $10 \mathrm{~mL}$ of the solution of the above prepared ligand, a mixture of sodium acetate $(3 \mathrm{mmol})$ and $\mathrm{Ln}\left(\mathrm{NO}_{3}\right)_{3} \cdot 6 \mathrm{H}_{2} \mathrm{O}(\mathrm{Ln}=\mathrm{Nd}$ or Sm) $(1 \mathrm{mmol})$ in ethanol $(10 \mathrm{~mL})$ was added. The mixture was stirred for $30 \mathrm{~min}$ and the resulting yellow slightly cloudy solution was filtered-off to discard a small quantity of $\mathrm{NaNO}_{3}$ and the filtrate was kept at $298 \mathrm{~K}$. Yellow powder began to appear after one day and was collected by filtration. Recrystallization by slow evaporation of an ethanol solution gave $\mathrm{X}$-ray quality crystals of the two compounds $\left[\mathrm{Nd}_{2} \mathrm{C}_{30} \mathrm{H}_{40} \mathrm{~N}_{8} \mathrm{O}_{12}\right] \cdot\left(\mathrm{NO}_{3}\right)_{2}$ (1) and $\left[\mathrm{Sm}_{2} \mathrm{C}_{30} \mathrm{H}_{40} \mathrm{~N}_{8} \mathrm{O}_{12}\right] \cdot\left(\mathrm{NO}_{3}\right)_{2}(2)$.

$\left[\mathrm{Nd}_{2} \mathrm{C}_{30} \mathrm{H}_{40} \mathrm{~N}_{8} \mathrm{O}_{12}\right] \cdot\left(\mathrm{NO}_{3}\right)_{2}(\mathbf{1})$. Yield $59 \%$. $\delta_{\mathrm{H}}\left(250 \mathrm{MHz}, \mathrm{DMSO}-\mathrm{d}_{6}\right)$ $11.185(2 \mathrm{H}, \mathrm{s}, \mathrm{H}-\mathrm{N}-\mathrm{N}) ; 8.542(2 \mathrm{H}, \mathrm{s}, \mathrm{H}-\mathrm{Py}) ; 8,152(2 \mathrm{H}, \mathrm{H}-\mathrm{Py})$; $8.096(2 \mathrm{H}, \mathrm{s}, \mathrm{H}-\mathrm{C}=\mathrm{N}) ; 7.980(2 \mathrm{H}, \mathrm{d}, J 7.50 \mathrm{~Hz}, \mathrm{H}-\mathrm{Py}) ; 7.805(2 \mathrm{H}, \mathrm{d}, J 8$ Hz, H-Py); 7.674(2H, d, J 8Hz, H-Py); 7.319(4H, d, J 8 Hz, H-Py); $6.826(2 \mathrm{H}, \mathrm{s}, \mathrm{H}-\mathrm{Py}) ; 4.722$ (s, broad, $\left.\mathrm{H}_{2} \mathrm{O}\right) . \delta_{\mathrm{C}}(250 \mathrm{MHz}$, DMSO-d $\mathrm{d}_{6}$ : 106.526 (C-8), 115.559 (C-10), 118.845 (C-4), 122.912 (C-2), 136.465 (C-3), 138.015 (C-9), 139.171 (C-6), 147.804 (C-11), 149.186 (C-1), 154.241 (C-7), 156.643 (C-5). Anal. calc. C, 32.25; H, 3.61; N, 12.54. Found: C, 32.30; H, 3.58; N, $12.46 \%$. $\mu_{\text {eff }}\left(\mu_{\mathrm{B}}\right): 3.14$. $\mathrm{L}_{\mathrm{M}}\left(\mathrm{S} \mathrm{cm} \mathrm{cmol}^{-1}\right): 89$. IR $\left(\mathrm{cm}^{-1}\right): 3222\left(v_{\mathrm{OH}}\right), 1583\left(v_{\mathrm{Py}}\right), 1577\left(v_{\mathrm{C}=\mathrm{N}}\right)$, $1555\left(v_{\mathrm{as}}\left(\mathrm{COO}^{-}\right)\right), 1448\left(v_{\mathrm{s}}\left(\mathrm{COO}^{-}\right)\right), 1370\left(v\left(\mathrm{NO}_{3}^{-}\right)\right), 825\left(\delta_{\mathrm{OH}}\left(\mathrm{H}_{2} \mathrm{O}\right)\right)$.

$\left[\mathrm{Sm}_{2} \mathrm{C}_{30} \mathrm{H}_{40} \mathrm{~N}_{8} \mathrm{O}_{12}\right] \cdot\left(\mathrm{NO}_{3}\right)_{2}(2)$. Yield $62 \%$. $\delta_{\mathrm{H}}\left(250 \mathrm{MHz}, \mathrm{DMSO}-\mathrm{d}_{6}\right)$ : $11.171(2 \mathrm{H}, \mathrm{s}, \mathrm{H}-\mathrm{N}-\mathrm{N}) ; 8.541(2 \mathrm{H}, \mathrm{d}, J 5 \mathrm{~Hz}, \mathrm{H}-\mathrm{Py}) ; 8,153(2 \mathrm{H}, \mathrm{d}, J$ $1.75 \mathrm{~Hz}, \mathrm{H}-\mathrm{Py}) ; 8.135(2 \mathrm{H}, \mathrm{s}, \mathrm{H}-\mathrm{C}=\mathrm{N}) ; 7.811(2 \mathrm{H}, \mathrm{d}, J 1.75 \mathrm{~Hz}$, H-Py); 7.683(2H, mult, H-Py); 7.677(2H, mult, H-Py); 7.304(4H, mult, H-Py); 6.823(2H, mult, H-Py). $\delta_{\mathrm{C}}(250 \mathrm{MHz}$, DMSO-d $\left.{ }_{6}\right): 106.508$ (C-8), 115.547 (C-10), 118.828 (C-4), 122.897 (C-2), 136.448 (C-3), 138.004 (C-9), 139.153 (C-6), 147.799 (C-11), 149.184 (C-1), 154.239 (C-7), 156.644 (C-5). Anal. calc.: C, 31.90; H, 3.57; N, 12.40. Found: C, C, 31.88; H, 3.52; N, $12.35 \% . \mu_{\text {eff }}\left(\mu_{\mathrm{B}}\right): 1.44$. $\mathrm{L}_{\mathrm{M}}\left(\mathrm{S} \mathrm{cm}^{2} \mathrm{~mol}^{-1}\right): 70$. IR $\left(\mathrm{cm}^{-1}\right): 3225\left(v_{\mathrm{OH}}\right), 1590\left(v_{\mathrm{Py}}\right), 1581\left(v_{\mathrm{C}=\mathrm{N}}\right)$, $1565\left(v_{\text {as }}\left(\mathrm{COO}^{-}\right)\right), 1450\left(v_{\mathrm{s}}\left(\mathrm{COO}^{-}\right)\right), 1368\left(v\left(\mathrm{NO}_{3}^{-}\right)\right), 821\left(\delta_{\mathrm{OH}}\left(\mathrm{H}_{2} \mathrm{O}\right)\right)$.

\subsection{Antioxidant Activities}

The methanol solution of $3.9 \mathrm{~mL} \mathrm{DPPH}^{\bullet}\left(40 \mathrm{mg} \mathrm{L}^{-1}\right)$ was added to test compounds $(100 \mu \mathrm{L})$ at different concentrations. The mixture was shaken vigorously and incubated in dark for $30 \mathrm{~min}$ at room temperature. After the incubation time, the absorbance of the solution was measured at $517 \mathrm{~nm}$ by using UV-vis spectrophotometer mini-1240 SHIMADZU. The DPPH $\bullet$ radical scavenger effect was calculated using the following equation:

Scavenging activity $(\%$ control $)=\left[\left(\mathrm{A}_{\text {control }}-\mathrm{A}_{\text {sample }}\right) / \mathrm{A}_{\text {control }}\right] \times 100$

where $A_{\text {control }}$ is the absorbance of the control reaction and $A_{\text {sample }}$ is the absorbance of the test compound. Tests were carried out in triplicate. Ascorbic acid was used as positive control.

\subsection{X-ray Crystal Structure Determination}

Details of the X-rays crystal structure solution and refinement are given in Table 1. Diffraction data were collected using an ENRAF NONIUS Kappa CCD diffractometer with graphite monochromatized Mo K $\alpha$ radiation $(\lambda=0.71073 \AA)$. All data were corrected for Lorentz and polarization effects. No absorption correction was applied. Complex scattering factors were taken from the program package SHELXTL. ${ }^{25}$ The structures were solved by direct methods which revealed the position of all non-hydrogen atoms. All the structures were refined on $F^{2}$ by a full-matrix least-squares procedure using anisotropic displacement parameters for all non-hydrogen atoms. ${ }^{26}$ The hydrogen atoms of water molecules and $\mathrm{NH}$ groups were located in the Fourier difference maps and refined. Others $\mathrm{H}$ atoms $\left(\mathrm{CH}\right.$ and $\mathrm{CH}_{3}$ groups) were geometrically optimized and refined as riding

Table 1 X-Ray single-crystal data.

\begin{tabular}{|c|c|c|}
\hline Empirical formula: & $\mathrm{Nd}_{2} \mathrm{C}_{30} \mathrm{H}_{40} \mathrm{~N}_{10} \mathrm{O}_{18}$ & $\mathrm{Sm}_{2} \mathrm{C}_{30} \mathrm{H}_{40} \mathrm{~N}_{10} \mathrm{O}_{18}$ \\
\hline Color/shape & Yellow/plate & Yellow/plate \\
\hline Molecular weight & 1117.20 & 1129.42 \\
\hline Crystal System, space group & Monoclinic, $P 2_{1} / c$ & Monoclinic, $P 2_{1} / c$ \\
\hline Temperature/K & 293 & 293 \\
\hline Crystal size $/ \mathrm{mm} \times \mathrm{mm} \times \mathrm{mm}$ & $0.15 \times 0.07 \times 0.08$ & $0.12 \times 0.09 \times 0.08$ \\
\hline $\mathrm{a} / \AA$ & $11.0927(8)$ & $11.0477(8)$ \\
\hline $\mathrm{b} / \AA$ & $17.9926(13)$ & $17.9254(13)$ \\
\hline$c / \AA ̊$ & $11.9395(9)$ & $11.9149(8)$ \\
\hline$\alpha /^{\circ}$ & 90.00 & 90.00 \\
\hline$\beta /^{\circ}$ & $115.274(5)$ & $115.489(5)$ \\
\hline$\gamma /{ }^{\circ}$ & 90.00 & 90.00 \\
\hline$V / \AA^{3}$ & $2154.9(3)$ & $2129.9(3)$ \\
\hline Z & 2 & 2 \\
\hline$D_{\text {cal }} / \mathrm{g} \mathrm{cm}^{-3}$ & 1.722 & 1.761 \\
\hline$\mu / \mathrm{mm}^{-1}$ & 2.46 & 2.81 \\
\hline$F(000)$ & 1108 & 1116 \\
\hline$\theta$ range for data collection $/{ }^{\circ}$ & $3.50-27.57$ & $4.68-27.52$ \\
\hline No. reflections/observed & $4934 / 4492$ & $4835 / 4315$ \\
\hline Data/restraints/parameter & $4934 / 7 / 286$ & $4835 / 7 / 288$ \\
\hline Goodness-of-fit & 1.10 & 1.05 \\
\hline Refinement method & Full-matrix least squares of $F^{2}$ & Full-matrix least squares of $F^{2}$ \\
\hline Final $\mathrm{R}$ indices $[\mathrm{I}>2 \sigma(\mathrm{I})]$ & $\mathrm{R} 1=0.0241, \mathrm{wR} 2=0.0522$ & $\mathrm{R} 1=0.0239, \mathrm{wR} 2=0.0585$ \\
\hline $\mathrm{R}$ indices (all data) & $\mathrm{R} 1=0.0285, \mathrm{wR} 2=0.0541$ & $\mathrm{R} 1=0.0280, \mathrm{wR} 2=0.0597$ \\
\hline$\Delta \rho / \mathrm{e} \AA^{-3}$ & $0.50,-0.35$ & $0.63,-0.88$ \\
\hline
\end{tabular}


model by AFIX instructions. Molecular graphics were generated using ORTEP-3. ${ }^{27}$ The chain bridging the two pyridine rings was found to be disordered such that the mean bond lengths in the chain are far from the mean values observed. This disorder may be explained by the fact that the sequence of atoms $\mathrm{C}(\mathrm{Py})-\mathrm{CH}=\mathrm{N}-\mathrm{NH}-\mathrm{C}(\mathrm{py})$ overlaps with the sequence $\mathrm{C}(\mathrm{py})-\mathrm{NH}-\mathrm{N}=\mathrm{CH}-\mathrm{C}(\mathrm{py})$, meaning two orientations of the ligand. In such a case for the refinement, one assume that atom $\mathrm{C}$ (of $\mathrm{CH}$ group) from one chain and atom $\mathrm{N}$ (of $\mathrm{NH}$ group) from the second chain occupy the same position. The same relates inversely. The instructions EXYZ and EADP of SHELXL were used to have the same atomic coordinates and displacement parameters of the disordered atoms. The occupancy factor refines close to 0.5 in the $\mathrm{Nd}$ complex and 60: $40 \%$ occupancy in the Sm complex.

\section{Results and Discussion}

\subsection{General Studies}

The acyclic tridentate ligand, 1-(pyridin-2-yl)-2-(pyridine-2ylmethylene)hydrazine, abbreviated as HL, was prepared by the $1: 1$ condensation reaction of 2-hydrazinopyridine and 2-pyridine carbaldehyde in ethanol. The reaction of $\mathrm{Ln}\left(\mathrm{NO}_{3}\right)_{3} \times \mathrm{H}_{2} \mathrm{O}$ and $\mathrm{NaOOCCH}_{3}$ with the prepared ligand solution, with a 1:3:1 molar ratio in ethanol gave yellow powder. The formulae of these powders are further confirmed as $\left\{\left[\mathrm{Ln}(\mathrm{HL})\left(\eta^{2}-\mathrm{CH}_{3} \mathrm{COO}\right)\left(\mathrm{H}_{2} \mathrm{O}\right)_{2}\right]\left(\mu-\mathrm{CH}_{3} \mathrm{COO}\right)_{2}\left[\mathrm{Ln}(\mathrm{HL})\left(\eta^{2}-\mathrm{CH}_{3} \mathrm{CO}\right.\right.\right.$ $\left.\left.\mathrm{O})\left(\mathrm{H}_{2} \mathrm{O}\right)_{2}\right]\right\}$. $\left(\mathrm{NO}_{3}\right)_{2}$, with $\mathrm{Ln}=\mathrm{Nd}$ and $\mathrm{Sm}$ (Scheme 1) by spectroscopic and $\mathrm{X}$-ray analysis.

The ${ }^{1} \mathrm{H}$ and ${ }^{13} \mathrm{C}$ NMR spectra of the hydrazino pyridine derivative ligand and its diamagnetic $\mathrm{Nd}$ (III) and $\mathrm{Sm}$ (III) complexes are recorded in DMSO- $\mathrm{d}_{6}$ as shown in experimental section. In the spectrum of the ligand a singlet appearing at $11.185 \mathrm{ppm}$ is attributed to the H-N proton. No shift of this signal was observed in the spectrum of both complexes indicating no deprotonation of the ligand and that the nitrogen atom supporting this proton is not involved in the coordination. The signal attributed to the $\mathrm{H}-\mathrm{C}=\mathrm{N}$ proton is slightly shifted to higher field from $8.144 \mathrm{ppm}$ in the free ligand to 8.096 and 8.135 ppm respectively in the spectra of the $\mathrm{Nd}$ and $\mathrm{Sm}$ complexes. This fact is indicative of an involvement of the azomethine in the complexation. The pyridine ring protons show also little difference shifts in the spectra of the complexes. Upon complexation the signals of the ${ }^{13} \mathrm{C}$ NMR spectra of the complexes show little difference with those of the spectrum of the free ligand. The signal of $\mathrm{C}=\mathrm{N}$ carbon atom appearing at $139.164 \mathrm{ppm}$ for the free ligand is slightly shifted to 139.171 ppm for $\mathrm{Nd}(\mathrm{III})$ complex and 139.153 ppm for Sm(III) complex. The spectrum of $\mathrm{Nd}$ (III) complex shows new broad signal at $4.722 \mathrm{ppm}$ due to the protons of the water molecules. The signals of the methyl groups of the acetate moieties are not observed in the NMR spectra of the complexes. They are probably obscured by the intense signal of the DMSO solvent.

Both IR spectra of the two complexes reveal bands which are assigned respectively to asymmetric $v_{\text {as }}(\mathrm{COO})$ and symmetric $v_{\mathrm{s}}(\mathrm{COO})$ stretching vibrations of the acetate group ${ }^{28}$ in the ranges $1565-1550$ and $1450-1440 \mathrm{~cm}^{-1}$. The positions of these asymmetric and symmetric bands are very close proximity in the two spectra of the complexes indicating that the coordination modes of the different acetate groups are similar in all these compounds. The values of $\Delta v=v_{\mathrm{as}}-v_{\mathrm{s}}$ are in the range admitted for multiple coordination modes of acetate groups. ${ }^{29}$ This coordination behaviours of the acetate groups were further confirmed by $\mathrm{X}$-ray studies of the complexes. In the X-ray structure of these binuclear complexes, each $\mathrm{Ln}(\mathrm{III})(\mathrm{Ln}=\mathrm{Nd}, \mathrm{Sm})$ ions have one acetate behaving as bidentate chelating and two others acting as bridges between the two lanthanide (III) ions. In both spectra medium bands in the range [1583-1590 $\mathrm{cm}^{-1}$ ] are observed and assigned to the $v(\mathrm{C}=\mathrm{N})$ stretching vibration which was expected for the free ligand at $\sim 1630 \mathrm{~cm}^{-1}$ as observed in the literature. ${ }^{30}$ This observation is a consequence of the decrease of the stretching force constant of the $\mathrm{C}=\mathrm{N}$ bond, indicating the involvement of the imino nitrogen in the lanthanide ion coordination sphere. The presence of band of medium intensity at $c a .3220$ and $820 \mathrm{~cm}^{-1}$ are due to the coordinated water molecules. ${ }^{31}$

The absorption bands at $\sim 1580 \mathrm{~cm}^{-1}$ are attributed to stretching vibration of the pyridine rings. The strong and sharp band observed in all the spectra at around $1370 \mathrm{~cm}^{-1}$ is characteristic of uncoordinated nitrate ion. ${ }^{32}$ Molar conductivities were measured for freshly prepared solutions in DMF and after standing for two<smiles>CCN(N)c1cccc(/C=N/N(C)c2ccccn2)n1</smiles>

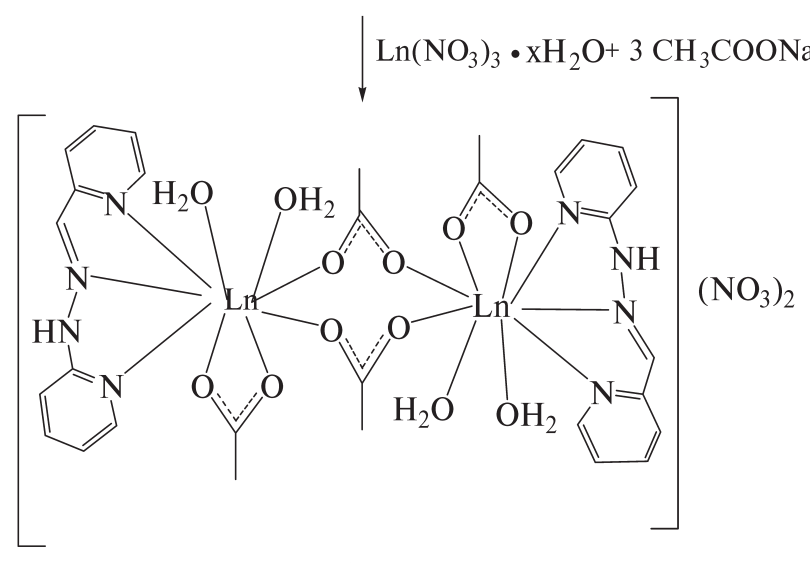

$\mathrm{Ln}=\mathrm{Nd}$ or $\mathrm{Sm}$

Scheme 1

Synthesis of the Schiff base ligand and the $\mathrm{Nd}(\mathrm{III})$ and $\mathrm{Sm}(\mathrm{III})$ complexes. 
weeks. The conductivities increased very slightly with time in DMF for all the complexes. The conductance values lie in the range observed for 1:1 electrolytes $\left(70-90 \mathrm{~cm}^{2} \Omega^{-1} \mathrm{~mol}^{-1}\right)$ in DMF. ${ }^{33}$ The $\mu_{\text {eff }}$ values of the lanthanide complexes show that they are paramagnetic. This paramagnetic behaviour is consistent with the presence of unpaired $4 \mathrm{f}$ electrons. The observed $\mu_{\text {eff }}$ values are in close proximity to the values for the free metal ions reported by Van Vleck and Frank. ${ }^{34}$ This shows that the magnetic moments of the $\mathrm{Ln}^{3+}$ ions are not affected by the ligand field. The 4 f-electrons are not involved in the coordination. These facts observed from the spectroscopy study are in accordance with the measured molar conductivities.

The results of the elemental analysis, IR spectra, magnetic moment measurements and conductivity study lead us to formulate the two binuclear Lanthanide(III) complexes as binuclear isotopic structures $\left\{\left[\mathrm{Ln}(\mathrm{HL})\left(\eta^{2}-\mathrm{CH}_{3} \mathrm{COO}\right)\left(\mathrm{H}_{2} \mathrm{O}\right)_{2}\right]\right.$ $\left.\left(\mu-\mathrm{CH}_{3} \mathrm{COO}\right)_{2}\left[\mathrm{Ln}(\mathrm{HL})\left(\eta^{2}-\mathrm{CH}_{3} \mathrm{COO}\right)\left(\mathrm{H}_{2} \mathrm{O}\right)_{2}\right]\right\} .\left(\mathrm{NO}_{3}\right)_{2}(\mathrm{Ln}=\mathrm{Nd}$, $\mathrm{Sm})$. These considerations on the geometrical features for these complexes are in complete agreement as that elucidated by X-ray crystallography of the $\mathrm{Nd}(\mathrm{III})$ and $\mathrm{Sm}(\mathrm{III})$ complexes.

\subsection{Molecular Structure of Complexes (1) and (2)}

Partially labelled plot of the binuclear structures of $\mathrm{Nd}$ (III) and Sm(III) complexes are respectively shown in Fig. 1a and Fig. 1b while the coordination polyhedra of the $\mathrm{Nd}$ (III) and Sm(III) ions are shown in Fig. 2a and Fig. 2b. Selected interatomic distances and angles are listed in Table 2. The structure of the complexes are consistence with $\left\{\left[\mathrm{Ln}(\mathrm{HL})\left(\eta^{2}-\mathrm{CH}_{3} \mathrm{COO}\right)\left(\mathrm{H}_{2} \mathrm{O}\right)_{2}\right](\mu\right.$ $\left.\left.\mathrm{CH}_{3} \mathrm{COO}\right)_{2}\left[\mathrm{Ln}(\mathrm{HL})\left(\eta^{2}-\mathrm{CH}_{3} \mathrm{COO}\right)\left(\mathrm{H}_{2} \mathrm{O}\right)_{2}\right]\right\}^{2+}$. Two non-coordinated nitrate anions per two Ln-containing unit, intervene as counter anions.

The structures of the $\mathrm{Nd}$ and Sm complexes of the 1-(pyridin-2-yl)-2-(pyridine-2-ylmethylene)hydrazine (HL) ligand were determined by X-ray crystallography. $\left\{\left[\mathrm{Nd}(\mathrm{HL})\left(\eta^{2}-\right.\right.\right.$ $\left.\left.\left.\mathrm{CH}_{3} \mathrm{COO}\right)\left(\mathrm{H}_{2} \mathrm{O}\right)_{2}\right]\left(\mu-\mathrm{CH}_{3} \mathrm{COO}\right)_{2}\left[\mathrm{Nd}(\mathrm{HL})\left(\eta^{2}-\mathrm{CH}_{3} \mathrm{COO}\right)\left(\mathrm{H}_{2} \mathrm{O}\right)_{2}\right]\right\}$ $\left(\mathrm{NO}_{3}\right)_{2}(\mathbf{1})$ and $\left\{\left[\mathrm{Sm}(\mathrm{HL})\left(\eta^{2}-\mathrm{CH}_{3} \mathrm{COO}\right)\left(\mathrm{H}_{2} \mathrm{O}\right)_{2}\right]\left(\mu-\mathrm{CH}_{3} \mathrm{COO}\right)_{2}\right.$ $\left.\left[\mathrm{Sm}(\mathrm{HL})\left(\eta^{2}-\mathrm{CH}_{3} \mathrm{COO}\right)\left(\mathrm{H}_{2} \mathrm{O}\right)_{2}\right]\right\}\left(\mathrm{NO}_{3}\right)_{2}(2)$ are isostructural and crystallize in the monoclinic space group $P 2_{1} / c$.

The crystallographic studies show that HL forms complexes with a 1:1 Ln:ligand ratio, in which the Schiff base acts as tridentate ligand. The coordination of the organic ligand to Ln results in the formation of two five membered (LnNCCN and LnNNCN) chelating rings. In these compounds each asymmetric unit comprises a single $\mathrm{Ln}^{3+}$ ion coordinated by one tridentate HL ligand, one bidentate chelating acetate ion, one bidentate bridging acetate ion, two coordinated water molecules and one uncoordinated nitrate group. The second half of the molecule is related by crystallography imposed inversion

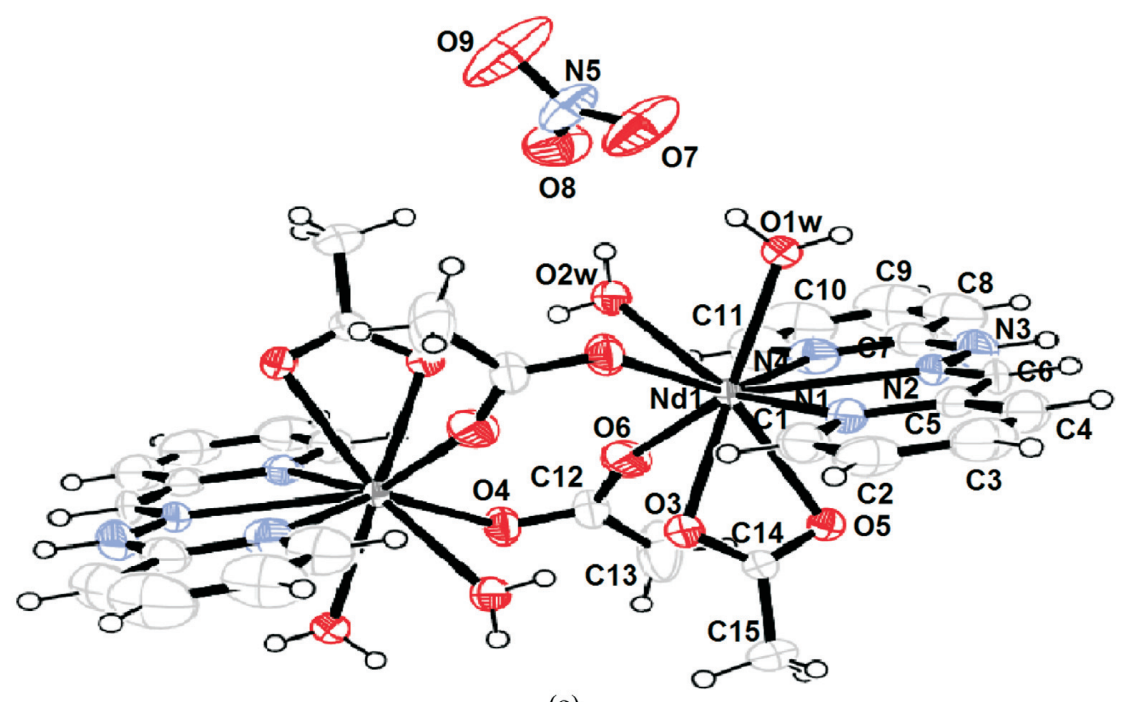

(a)

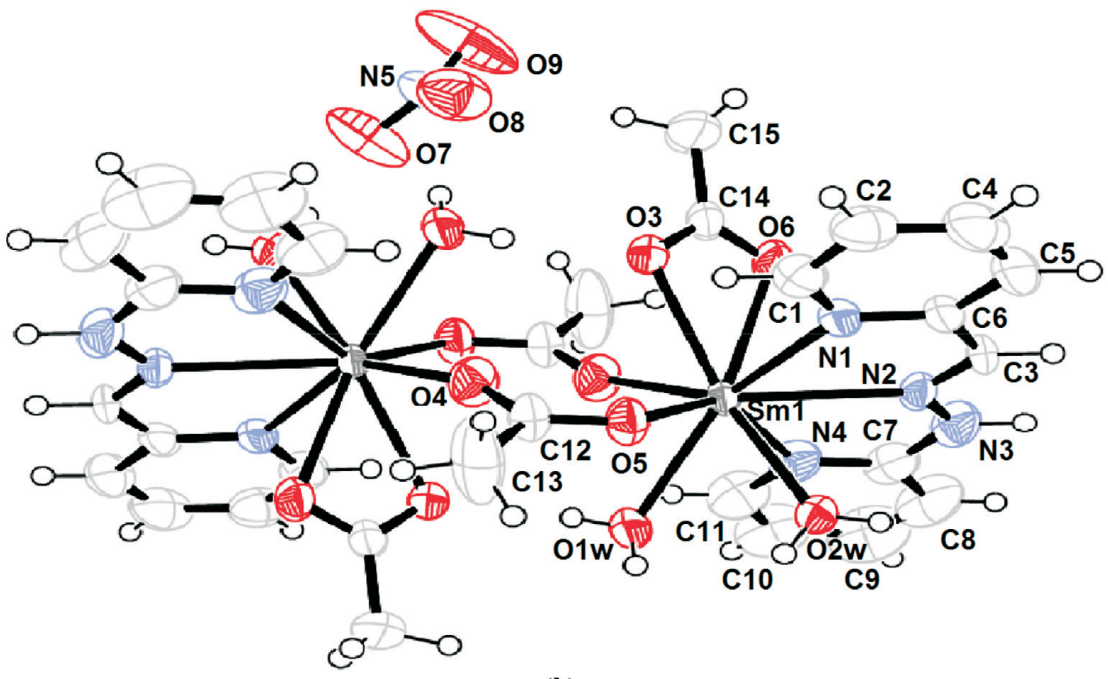

(b)

Figure 1 Crystal structure of the centrosymmetric binuclear $\mathrm{Nd}(\mathrm{III})$ (a) and $\mathrm{Sm}(\mathrm{III})$ (b) complexes, showing the atom-numbering scheme in the asymmetric unit (half of the binuclear complex and one nitrate anion). 


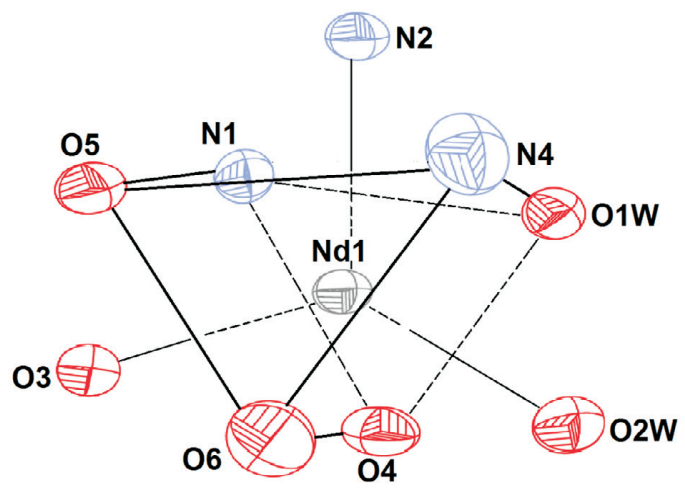

a

Figure 2 Plot showing the coordination sphere of $\mathrm{Nd}(\mathbf{a})$ and $\mathrm{Sm}(\mathbf{b})$.

symmetry (symmetry code: - $\mathrm{x},-\mathrm{y},-\mathrm{z}$ ). The coordination geometry around each nine-coordinated $\mathrm{Ln}$ (III) ion can be described as a distorted tricapped prism formed by the tridentate ligand HL acting through two pyridine nitrogen atoms and one imino nitrogen atom, two oxygen atoms from a bidentate chelating acetate ion, two oxygen atoms from two different bidentate bridging acetate ions and two oxygen atoms from two water molecules. The Nd-N distances are 2.675(3) $\AA$, 2.639(2) $\AA$ and 2.637(2) $\AA$ while the Sm-N lengths are 2.647(3) $\AA$, 2.609(2) $\AA$ and $2.606(2) \AA$, with the longer distance belonging to the orthohydrazino substituted pyridyl nitrogen atom in both complexes. The Ln-O distances, when $\mathrm{O}$ is from bidentate cheating acetate, are in the ranges 2.522(2)-2.550(2) $\AA$ for 1 and 2.502(2)-2.250(2) $\AA$ for 2, respectively; the Ln-O distances, when $\mathrm{O}$ is from bidentate bridging acetate, are in the range of 2.377(2)-2.419(2) $\AA$ for 1 and

Table 2 Selected bond lengths $(\AA)$ and bond angles $\left({ }^{\circ}\right)$ for $\mathrm{Nd}$ and Sm complexes.

\begin{tabular}{lc|ll}
\hline \multicolumn{2}{c}{ Nd complex } & \multicolumn{2}{c}{ Sm complex } \\
\hline Nd1-O6 & $2.377(2)$ & Sm1-O4 & $2.345(2)$ \\
Nd1-O4i & $2.419(2)$ & Sm1-O5i & $2.384(2)$ \\
Nd1-O2W & $2.506(2)$ & Sm1-O2W & $2.4767(19)$ \\
Nd1-O1W & $2.5130(19)$ & Sm1-O1W & $2.479(2)$ \\
Nd1-O3 & $2.522(2)$ & Sm1-O3 & $2.502(2)$ \\
Nd1-O5 & $2.550(2)$ & Sm1-O6 & $2.520(2)$ \\
Nd1-N2 & $2.637(2)$ & Sm1-N2 & $2.606(2)$ \\
Nd1-N1 & $2.639(2)$ & Sm1-N1 & $2.609(2)$ \\
Nd1-N4 & $2.675(3)$ & Sm1-N4 & $2.647(3)$ \\
O4-C12 & $1.240(3)$ & O4-C12 & $1.242(4)$ \\
O6-C12 & $1.245(3)$ & O5-C12 & $1.245(3)$ \\
O3-C14 & $1.250(4)$ & O3-C14 & $1.249(4)$ \\
O5-C14 & $1.267(4)$ & O6-C14 & $1.270(4)$ \\
O6-Nd1-O1W & $140.49(8)$ & O4-Sm1-O2W & $140.38(8)$ \\
O2W-Nd1-O3 & $128.06(6)$ & O2W-Sm1-O3 & $141.67(8)$ \\
O1W-Nd1-O3 & $141.72(7)$ & O1W-Sm1-O3 & $127.35(7)$ \\
O4i-Nd1-O5 & $127.80(8)$ & O5i-Sm1-O6 & $128.07(8)$ \\
O2W-Nd1-O5 & $144.74(8)$ & O2W-Sm1-O6 & $135.25(7)$ \\
O1W-Nd1-O5 & $134.83(7)$ & O1W-Sm1-O6 & $144.11(8)$ \\
O6-Nd1-N2 & $127.34(8)$ & O4-Sm1-N2 & $127.60(8)$ \\
O4i-Nd1-N2 & $128.46(7)$ & O5i-Sm1-N2 & $129.49(8)$ \\
O2W-Nd1-N2 & $119.35(7)$ & O1W-Sm1-N2 & $120.00(7)$ \\
O3-Nd1-N2 & $111.85(7)$ & O3-Sm1-N2 & $111.91(7)$ \\
O6-Nd1-N1 & $143.33(8)$ & O4-Sm1-N1 & $143.04(8)$ \\
O2W-Nd1-N1 & $142.24(8)$ & O1W-Sm1-N1 & $142.26(8)$ \\
O4i-Nd1-N4 & $147.02(8)$ & O5i-Sm1-N4 & $146.59(8)$ \\
O3-Nd1-N4 & $130.16(8)$ & N1-Sm1-N4 & $123.05(8)$ \\
\hline
\end{tabular}

Symmetry code: (i) $-x+1,-y+1,-z+1$.

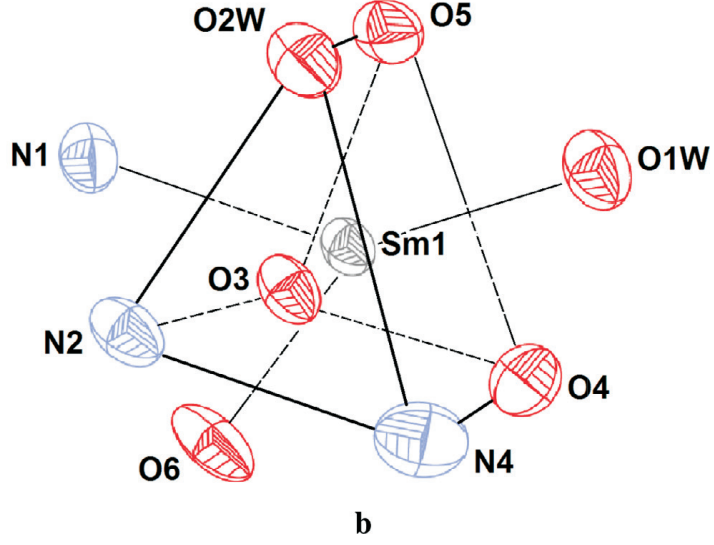

2.345(2)-2.384(2) Å for 2. In both complexes the Ln-O distances from bidentate cheating acetate are longer than those from bidentate bridging acetate. These observations are in agreement with those found in literature..$^{28}$ The $\mathrm{Ln}-\mathrm{Ow}$ distances are in the range of 2.506(2)-2.513(2) $\AA$ for 1 and 2.477(2)-2.479(2) $\AA$ for 2 and are comparable to the values in the complex $\left[\mathrm{Ln}_{2}(\mathrm{~L})_{6}\left(\mathrm{H}_{2} \mathrm{O}\right)_{2}\right] \cdot 2 \mathrm{H}_{2} \mathrm{O}$ (where $\mathrm{Ln}=\mathrm{Nd}$ or $\mathrm{Sm}$ and $\mathrm{HL}=$ 4-Hydroxy-6-methylnicotinic acid). ${ }^{35}$ The bond lengths between carbon and oxygen atoms which are observed in both acetate groups [1.240 (3) A-1.270 (4) $\AA$ ] are shorter than that of a simple $\mathrm{C}-\mathrm{O}$ bond $(1.430 \AA)$ and longer than that of a $\mathrm{C}=\mathrm{O}$ double bond type $(1.220 \AA)$. These observations indicate that the bond CO in coordinate acetate moieties has an intermediate character between $\mathrm{C}-\mathrm{O}$ and $\mathrm{C}=\mathrm{O}$.

The average lengths of the $\mathrm{Ln}-\mathrm{O}$, when $\mathrm{O}$ is from bidentate cheating acetate are 2.536(2) $\AA$ for $\mathbf{1}$ and 2.511(2) $\AA$ for 2, Ln-N are 2.650(2) $\AA$ for 1 and 2.621(3) $\AA$ for $\mathbf{2}$ and Ln-O bonds when O is from bidentate bridging acetate $(2.509(2) \AA$ for 1 and 2.478(2) $\AA$ for 2. All these values are comparable to those found in carboxylate complexes. ${ }^{36-39}$ The Ln-Ln distance are $5.2150 \AA$ for 1 and $4.9550 \AA$ for 2 . The C6-N2 (1) and C3-N2 (2) distances and there related symmetry are consistent with double bond character. The bond angles of the ligands, which involve the $\mathrm{Nd}(\mathrm{III})$ ion, are respectively $\mathrm{N} 1-\mathrm{Nd} 1-\mathrm{N} 2\left(61.03(8)^{\circ}\right), \mathrm{N} 2-\mathrm{Nd} 1-\mathrm{N} 4\left(60.79(9)^{\circ}\right)$ and are slightly largest than those with bidentate oxygen atoms O5-Nd1-O3 (51.08(7) ${ }^{\circ}$ ). The bond angle of the bridged oxygen atoms of the acetate groups, $\mathrm{O} 6-\mathrm{Nd} 1-\mathrm{O} 4^{\mathrm{i}}$, is $104.18(8)^{\circ}$. The three sets of donor atoms [(N1, O1W, O6); (N2, O3, O2W) and $\left.\left(\mathrm{O} 5, \mathrm{O} 4{ }^{\mathrm{i}}, \mathrm{N} 4\right)\right]$ form three planes in complex 1 . The angle sum subtended by the three sets of donor atoms at $\mathrm{Nd} 1$ are respectively $359.69^{\circ}, 359.26^{\circ}$ and $359.81^{\circ}$. In the complex 2 the angle sum subtended by the three sets of donor atoms at $\mathrm{Sm} 1$ are respectively $359.67^{\circ}, 359.66^{\circ}$ and $356.79^{\circ}$. Two possible coordination polyhedra with nine vertexes are known. For Nd1 and Sm1, the best representation of environment geometry is a distorted tricapped trigonal prism, the three cap positions being occupied by O3, N2 and O2W for Nd1 and N1, O6, O1W for $\mathrm{Sm} 1$ (Fig. 2). The mean bond lengths in the chain $\mathrm{C}(\mathrm{Py})-\mathrm{CH}=$ N-NH-C(py) are 1.425, 1.297, 1.309 and $1.416 \AA$. These bonds values are significantly far from the corresponding mean values for this ligand found on the CSD data (1.450(17) 1.283(15) $1.349(12) 1.376(16) \AA$ ). This is indicative of the considerable disorder detected for the $\mathrm{C}(\mathrm{Py})-\mathrm{CH}=\mathrm{N}-\mathrm{NH}-\mathrm{C}(\mathrm{py})$ chain bridging the two pyridine rings.

Intramolecular hydrogen-bond contacts involve the $\mathrm{OH}$ groups of the coordinated water molecules and the $\mathrm{O}-\mathrm{NO}_{2}$ of the nitrate counter-ions. Furthermore, the intermolecular hydrogen bonds plays an important role in the fabrication of stacking 
structure of the complexes. Intermolecular hydrogen-bond contacts involve $\mathrm{NH}$ groups of the organic ligand as well as the hydroxyl groups of coordinated water molecule and the coordinated $\mathrm{O}$ atoms of the bidentate-chelating acetate (Table 3). Intermolecular hydrogen-bond contacts involving $\mathrm{OH}$ groups of the coordinated water molecules and $\mathrm{O}$ atoms of uncoordinated nitrate groups are also observed (Table 3). The hydrogen bonds connect the chains into a three-dimensional network (Fig. 3.). The two complexes are isomorphous and have a similar framework.

\subsection{Antioxidant Activities Study}

To evaluate the antioxidant activity of organic or inorganic compounds, the method of scavenging $\mathrm{DPPH}^{\bullet}$ is largely used in literature..$^{40-42}$ The antioxidant activities of the ligand HL and its Nd(III) (1) and Sm(III) (2) complexes have been substantially investigated. Fig. 4 shows the plots of $\mathrm{DPPH}^{\bullet}$ free radical scavenging activity (\%) for ascorbic acid, the ligand HL and its two Ln(III) complexes. The effect of antioxidants on DPPH ${ }^{\bullet}$ radical scavenging is due to their hydrogen donating ability. $\mathrm{DPPH}^{\bullet}$ is a stable free radical and accepts an electron or hydrogen radical to become a stable molecule. It is observed that the scavenging activity increases with increasing lanthanide complex concentration in the range tested. The free ligand HL has scavenging activity between $5 \%$ and $60 \%$ within the investigated concentration range due to the $\mathrm{NH}$ groups which can react with $\mathrm{DPPH}{ }^{\bullet}$ radical by the typical $\mathrm{H}$-abstraction ${ }^{43}$ reaction to form a stable radical. As shown in Fig. 4, Ln(III) complexes are significantly more efficient in quenching $\mathrm{DPPH}^{\bullet}$ radical than the free ligand HL. In fact, when the ligand HL is coordinated to $\mathrm{Ln}^{3+}$ the electron density is drawn from the nitrogen atom resulting in $\mathrm{N}-\mathrm{H}$ bond more polarized. The hydrogen atom has a greater tendency to ionize than those in the free ligand HL in methanol. The $\mathrm{H}$-abstraction reaction possibility is drastically increased.

The values of IC50 of the ligand HL and complexes (1) and (2) at $40 \mathrm{mg} \mathrm{L}^{-1}$ on the DPPH ${ }^{\bullet}$ radical scavenging effects are $82.38 \pm$ $0.01,8.01 \pm 0.02$ and $10.65 \pm 0.01 \mathrm{mM}$, respectively. The values of IC50 present the order $\mathbf{1}<\mathbf{2}<\mathbf{H L}$. These observations are indicative that the $\mathrm{DPPH}^{\bullet}$ radical scavenging effects of $\mathrm{Ln}(\mathrm{III})$ complexes are higher than that of the free ligand. These values are compared with the ability of ascorbic acid which is a wellknown natural antioxidant compound. The $50 \%$ inhibitory concentration (IC50) value of the ascorbic acid is $0.980 \pm 0.005 \mathrm{mM}$. These results imply that the ascorbic acid has a preferable ability to scavenge the $\mathrm{DPPH}^{\bullet}$ than the two $\mathrm{Ln}(\mathrm{III})$ complexes which have better IC50 than the free ligand. It can be concluded that the less scavenging activity exhibited by the ligand can be

Table 3 Hydrogen bonds for the complexes.

\begin{tabular}{|c|c|c|c|c|}
\hline \multicolumn{5}{|c|}{ Nd complex } \\
\hline$D-\mathrm{H} \cdots A$ & $D-\mathrm{H}$ & $H \cdots A$ & $D \cdots A$ & $D-\mathrm{H} \cdots A$ \\
\hline O1W-H1WA $\cdots$ O7 & $0.824(17)$ & $1.971(19)$ & $2.789(4)$ & $172(3)$ \\
\hline $\mathrm{O} 1 \mathrm{~W}-\mathrm{H} 1 \mathrm{WB} \cdots \mathrm{O}^{\mathrm{b}}$ & $0.809(17)$ & $2.20(2)$ & $2.966(4)$ & $158(3)$ \\
\hline $\mathrm{O} 2 \mathrm{~W}-\mathrm{H} 2 \mathrm{WA} \cdots \mathrm{O} 8$ & $0.822(18)$ & $1.96(2)$ & $2.764(4)$ & $167(3)$ \\
\hline $\mathrm{O} 2 \mathrm{~W}-\mathrm{H} 2 \mathrm{WB} \cdots \mathrm{O}^{\mathrm{a}}$ & $0.815(17)$ & $1.95(2)$ & $2.737(3)$ & $163(4)$ \\
\hline $\mathrm{N} 3-\mathrm{H} 3 \mathrm{~N} \cdots \mathrm{O} 5^{c}$ & $0.939(18)$ & $2.45(3)$ & $3.186(4)$ & $136(3)$ \\
\hline \multicolumn{5}{|c|}{ Sm complex } \\
\hline $\mathrm{O} 1 \mathrm{~W}-\mathrm{H} 1 \mathrm{WA} \cdots \mathrm{O}^{\mathrm{d}}$ & $0.815(17)$ & $1.95(2)$ & $2.753(3)$ & $169(4)$ \\
\hline $\mathrm{O} 1 \mathrm{~W}-\mathrm{H} 1 \mathrm{WB} \cdots \mathrm{O} 8$ & $0.803(18)$ & $1.98(2)$ & $2.753(4)$ & $162(4)$ \\
\hline $\mathrm{O} 2 \mathrm{~W}-\mathrm{H} 2 \mathrm{WA} \cdots \mathrm{O}^{\mathrm{e}}$ & $0.811(17)$ & $2.20(2)$ & $2.964(4)$ & $158(4)$ \\
\hline $\mathrm{O} 2 \mathrm{~W}-\mathrm{H} 2 \mathrm{WA} \cdots \mathrm{O}^{\mathrm{e}}$ & $0.811(17)$ & $2.62(2)$ & $3.362(4)$ & $152(4)$ \\
\hline $\mathrm{O} 2 \mathrm{~W}-\mathrm{H} 2 \mathrm{WB} \cdots \mathrm{O} 7$ & $0.811(18)$ & $2.00(2)$ & $2.795(4)$ & $167(4)$ \\
\hline $\mathrm{N} 3-\mathrm{H} 3 \mathrm{~N} \cdots \mathrm{O} 6^{\mathrm{f}}$ & $0.949(18)$ & $2.56(3)$ & $3.254(4)$ & $131(3)$ \\
\hline
\end{tabular}

Symmetry codes: (a) $-x+1,-y+1,-z+1 ;(b) x,-y+1 / 2, z-1 / 2 ;(c)-x+1,-y+1,-z,(d)-x+1,-y+1,-z+1 ;(e) x,-y+1 / 2, z+1 / 2 ;(f)-x+1,-y+1,-z+2$.

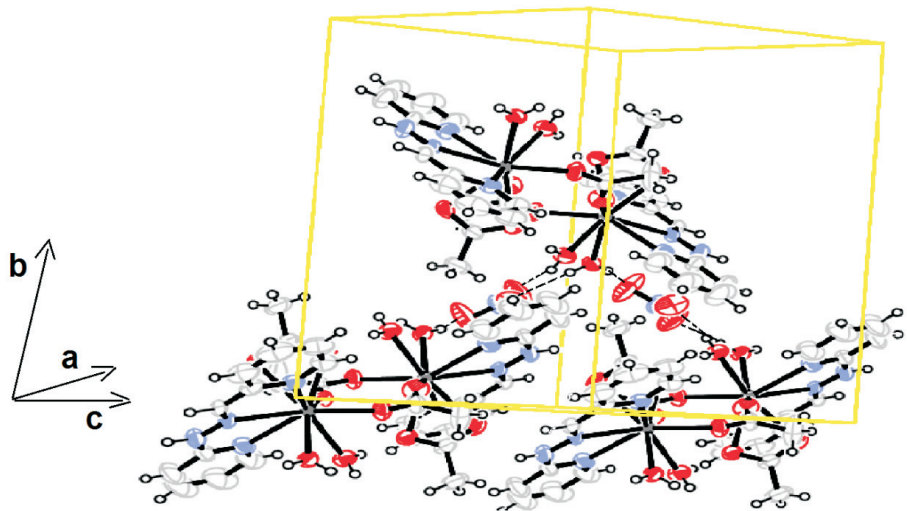

a

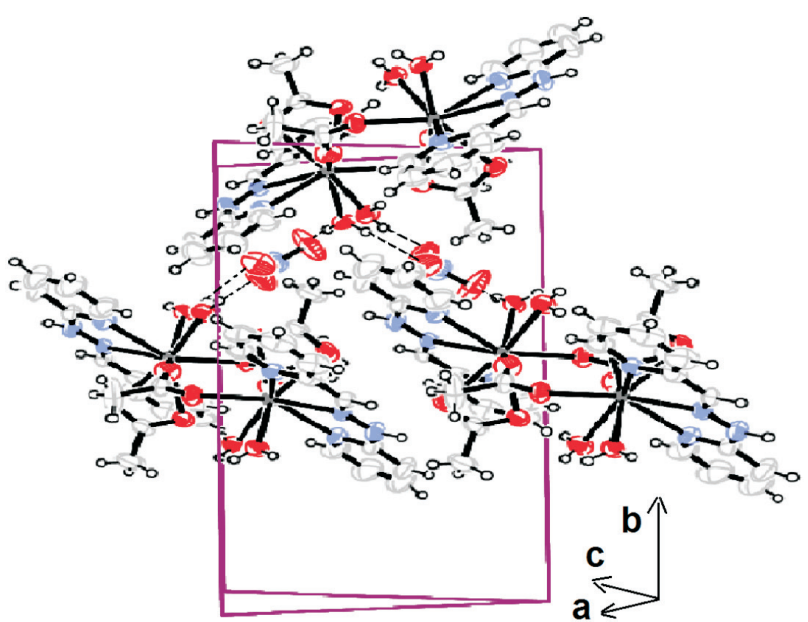

Figure 3 Chains of hydrogen bonding in the crystal lattice in $\mathrm{Nd}(\mathbf{a})$ and $\mathrm{Sm}(\mathbf{b})$ complexes. 


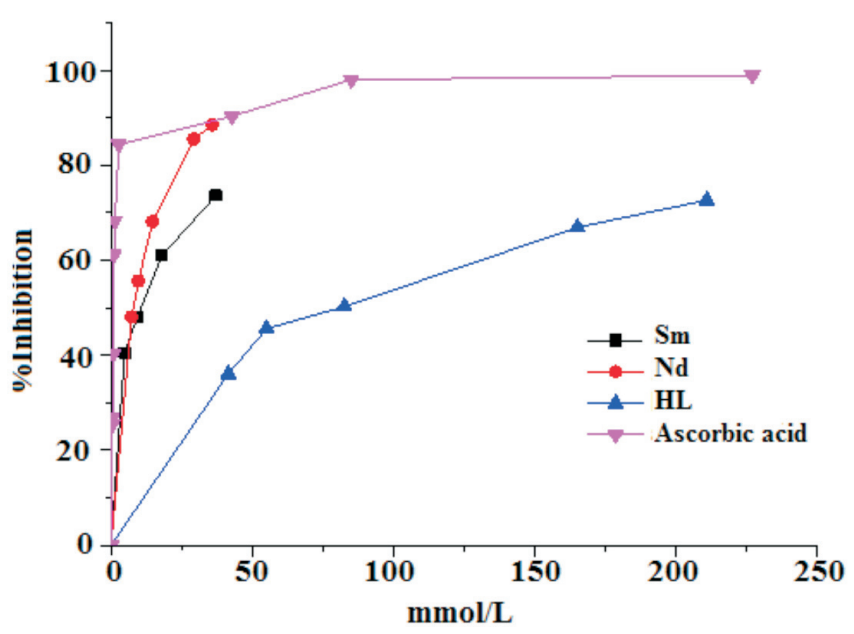

Figure 4 Antioxidant activity of the ligand and the lanthanide complexes.

explained by the chelation of ligand with the central metal atom. ${ }^{30}$

\section{Conclusion}

In conclusion, a tridentate ligand $\left(\mathrm{N}_{4}\right)$ was synthetized and reacted with lanthanide nitrate and sodium acetate to yield binuclear lanthanide compounds of $\mathrm{Nd}$ and $\mathrm{Sm}$. These complexes were characterized by spectroscopic studies, elemental analyses, molar conductivity and room temperature magnetic moment measurements. Suitable X-ray crystals diffraction were obtained for the $\mathrm{Nd}$ and $\mathrm{Sm}$ complexes. The X-ray structure determination reveal that the $\mathrm{Ln}^{3+}$ ion is nine-coordinated with two pyridine nitrogen atoms, one imine nitrogen atom, four oxygen atoms from acetate groups and two water oxygen atoms resulting in a distorted tricapped trigonal prism geometry. The antioxidant activities of the complexes were investigated. For DPPH ${ }^{\bullet}$, these lanthanide complexes show activity concentration dependence.

\section{Supplementary Data}

CCDC 1496016 (1) and 1496018 (2) contain the supplementary crystallographic data for samarium and the neodymium complexes respectively. These data can be obtained free of charge via http://www.ccdc.cam.ac.uk/conts/ retrieving.html, or from the Cambridge Crystallographic Data Centre, 12 Union Road, Cambridge CB2 1EZ, UK; fax: +44 1223 336033; or e-mail: deposit@ccdc.cam.ac.uk.

\section{References}

1 S. Procházková, J. Hraníček, V. Kubíček and P. Hermann, Formation kinetics of europium(III) complexes of DOTA and its bis(phosphonate) bearing analogs. Polyhedron, 2016, 111, 143-149.

2 Z.-Q. Xu, X.-J. Mao, L. Jia, J. Xu, T.-F. Zhu, H.-X. Cai, H.-Y. Bie, R.-H. Chen and T.-L. Ma, Synthesis, characterization and anticancer activities of two lanthanide(III) complexes with a nicotinohydrazone ligand. J. Mol. Struct., 2015, 1102, 86-90.

3 X. Yang, R.A. Jones and S. Huang, Luminescent $4 \mathrm{f}$ and d-4f polynuclear complexes and coordination polymers with flexible salentype ligands. Coord. Chem. Rev., 2014, 273-274, 63-75.

4 S.-D. Han, X.-H. Miao, S.-J. Liu and X.-H. Bu, Magnetocaloric effect and slow magnetic relaxation in two dense $(3,12)$-connected lanthanide complexes. Inorg. Chem. Front., 2014, 1, 549-552.

5 R.W.Wen, S.D. Han, G.J. Ren, Z. Chang, Y.W. Li and X.H. Bu, A flexible zwitterion ligand based lanthanide metal-organic framework for luminescence sensing of metal ions and small molecules. Dalton Trans., 2015, 44, 10914-10917.

6 D. Tian, Y. Li, R.Y. Chen, Z. Chang, G.Y. Wang and X.H. Bu, A luminescent metal-organic framework demonstrating ideal detection ability for nitroaromatic explosives. J. Mater. Chem. A, 2014, 2, 1465-1470.

7 N. Cakić, S. Gündüz, R. Rengarasu and G. Angelovski, Synthetic strategies for preparation of cyclen-based MRI contrast agents. Tetrahedron Lett., 2015, 56, 759-765.

8 H. Zhou, Y. Jiang, M. Chen, Y. Wang, Y. Yao, B. Wu and D. Cui, Synthesis and characterization of lanthanide amides bearing phenoxy(quinolinyl)amide ligand and their application in the ring-opening polymerization of 1,4-dioxan-2-one. J. Organomet. Chem., 2014, 763764, 52-59.

9 M.G. Lahoud, R.C.G. Frem, D.A. Gálico, G. Bannach, M.M. Nolasco, R.A.S. Ferreira and L.D. Carlos, Intriguing light-emission features of ketoprofen-based $\mathrm{Eu}(\mathrm{III})$ adduct due to a strong electron-phonon coupling. J. Lumin., 2016, 170, 357-363.

10 B. Cristóvão and Z. Hnatejko, Lanthanide(III) compounds with the $\mathrm{N}_{2} \mathrm{O}_{4}$-donor Schiff base. Synthesis, spectral, thermal, magnetic and luminescence properties. J. Mol. Struct., 2015, 1088, 50-55.

11 (a) F.B. Tamboura, P.M. Haba, M. Gaye, A.S. Sall, A.H. Barry and T. Jouini, Structural studies of bis-(2,6-diacetylpyridine-bis-(phenylhydrazone)) and X-ray structure of its Y(III), $\operatorname{Pr}(\mathrm{III}), \mathrm{Sm}(\mathrm{III})$ and Er(III) complex. Polyhedron, 2004, 23, 1191-1197. (b) P.M. Haba, F.B. Tamboura, O. Diouf, M. Gaye, A.S. Sall, C.A. Baldé and C. Slebodnick, Preparation, spectroscopic studies and X-ray structure of homobinuclear lanthanide(III) complexes derived from 2,6-diformyl-4chlorophénol-bis-(2'-hydroxy-benzoylhydrazone). Bull. Chem. Soc. Ethiop., 2006, 20, 45-54.

12 F.B. Tamboura, O. Diouf, A.H. Barry, M. Gaye and A.S. Sall, Dinuclear lanthanide(III) complexes with large-bite Schiff bases derived from 2,6-diformyl-4-chlorophenol and hydrazides: synthesis, structural characterization and spectroscopic studies. Polyhedron, 2012, 43, 97-103.

13 H. Sun, L. Wu, W. Yuan, J. Zhao and Y. Liu, Phenoxo-O bridged dinuclear lanthanide complexes based on a multitooth Schiff base ligand: structures, fluorescence properties and single-molecule magnet behavior. Inorg. Chem. Commun., 2016, 70, 164-167.

14 J.-P. Costes, G. Novitchi and C. Lebrun, Synthesis and characterization of new heterodinuclear (4f, $\left.4 \mathrm{f}^{\prime}\right)$ lanthanide complexes. J. Alloys Compd., 2004, 374, 377-381.

15 P.A. Vigato and S. Tamburini, The challenge of cyclic and acyclic Schiff bases and related derivatives. Coord. Chem. Rev., 2004, 248, 1717-2128.

16 U. Casellato, S. Tamburini, P. Tomasin and P.A. Vigato, Cyclic and acyclic compartmental Schiff bases, their reduced analogues and related mononuclear and heterodinuclear complexes. Inorg. Chim. Acta, 2004, 357, 4191-4207.

17 C.A.F. de Oliveira, F.F. da Silva, I. Malvestiti, V.R. dos S. Malta, J.L. Dutra, N.B. da Costa Jr., R.O. Freire and S.A. Júnior, Effect of temperature on formation of two new lanthanide metal-organic frameworks: synthesis, characterization and theoretical studies of Tm(III)succinate. J. Solid State Chem., 2013, 197, 7-13.

18 F.-Q. Wang, X.-J. Zheng, Y.-H. Wan. , K.-Z. Wang and L.-P. Jin, Architecture of zero-, one-, two- and three-dimensional structures based on metal ions and pyrazine-2,6-dicarboxylic acid. Polyhedron, 2008, 27, $717-726$.

19 J.R. Anacona and M. Rincones, Tridentate hydrazone metal complexes derived from cephalexin and 2-hydrazinopyridine: synthesis, characterization and antibacterial activity. Spectrochim. Acta, Part A, 2015, 141, 169-175.

20 B. Guhathakurta, A.B. Pradhan, S. Das, N. Bandyopadhyay, L.Lu, M. Zhu and J.P. Naskar, Spectroscopic and molecular docking studies on the interaction of human serum albumin with copper(II) complexes. Spectrochim. Acta, Part A, 2017, 173, 740-748.

21 M.V. Angelusiu, S.-F. Barbuceanu, C. Draghici and G.L. Almajan, New $\mathrm{Cu}(\mathrm{II}), \mathrm{Co}(\mathrm{II}), \mathrm{Ni}(\mathrm{II})$ complexes with aroyl-hydrazone based ligand. Synthesis, spectroscopic characterization and in vitro antibacterial evaluation. Eur. J. Med. Chem., 2010, 45, 2055-2062.

22 K. Mohanan, B.S. Kumari and G. Rijulal, Microwave assisted synthesis, spectroscopic, thermal, and antifungal studies of some lanthanide(III) complexes with a heterocyclic bishydrazone. J. Rare Earths, 2008, 26, 16-21.

23 Picón-Ferrer, F. Hueso-Ureña, N.A. Illán-Cabeza, S.B. JiménezPulido, J.M. Martínez-Martos, M. J. Ramírez-Expósito and M. N. Moreno-Carretero, Chloro-fac-tricarbonylrhenium(I) complexes of asymmetric azines derived from 6-acetyl-1,3,7-trimethylpteridine-2,4(1H,3H)-dione with hydrazine and aromatic aldehydes: preparation, structural characterization and biological activity 
against several human tumor cell lines. J. Inorg. Biochem., 2009, 103, 94-100.

24 A.B. Thomas, R.K. Nanda, L.P. Kothapalli and S.C. Hamane, Synthesis and biological evaluation of Schiff's bases and 2-azetidinones of isonocotinyl hydrazone as potential antidepressant and nootropic agents. Arabian J. Chem., 2016, 9, S79-S90.

25 G.M. Sheldrick, SHELXTL Version 5.10, 1997, Bruker AXS Inc., Madison, Wisconsin, USA

26 G.M. Sheldrick, SHELXTL-97, 1997, University of Göttingen, Göttingen, Germany.

27 L.J. Farrugia, ORTEP-3 for Windows - a version of ORTEP-III with a Graphical User Interface (GUI). J. Appl. Cryst., 1997, 30, 565.

28 N.C. Anastasiadis, I. Mylonas-Margaritis, V. Psycharis, C.P. Raptopoulou, D.A. Kalofolias, C.J. Milios, N. Klouras and S.P. Perlepes, Dinuclear, tetrakis(acetato)-bridged lanthanide(III) complexes from the use of 2-acetylpyridine hydrazine. Inorg. Chem. Commun., 2015, 51, 99-102.

29 B. Benmerad, K. Aliouane, N. Rahahlia, A. Guehria-Laïdoudi, S. Dahaoui and C. Lecomte, Studies of two lanthanide coordination polymers built up from dinuclear units. J. Rare Earths, 2013,31, 85-93.

30 M.T. Kaczmarek, R. Jastrząb, M. Kubicki, M. Gierszewski and M. Sikorski, Supramolecular polymer of Schiff base gadolinium complex: synthesis, crystal structure and spectroscopic properties. Inorg. Chim. Acta, 2015, 430, 108-113.

31 K. Nakamoto, Infrared and Raman Spectra of Inorganic and Coordination Compounds, 3rd edn., Wiley-Interscience, New York, 1978.

32 (a) S. Chandra, M. Tyagi, S. Rani and S. Kumar, Lanthanide complexes derived from hexadentate macrocyclic ligand: synthesis, spectroscopic and thermal investigation. Spectrochim. Acta, Part A, 2010, 75 835-840. (b) Z.A. Taha, A.M. Ajlouni, W. Al-Momani and A.A. Al-Ghzawi, Syntheses, characterization, biological activities and photophysical properties of lanthanides complexes with a tetradentate Schiff base ligand. Spectrochim. Acta, Part A, 2011, 81, 570-577.

33 W.J. Geary, The use of conductivity measurements in organic solvents for the characterization of coordination compounds. Coord. Chem. Rev. 1971, 7, 81-122.
34 J.H.V. Vleck and A. Frank, The Effect of second order Zeeman terms on magnetic susceptibilities in the rare earth and iron groups. Phys. Rev. 1929, 34, 1494, 1625.

35 Q. Guo, X.-M. Gao, P. Wang and F.-C. Liu, Hydrothermal syntheses, crystal structures and properties of lanthanide complexes with 4 hydroxy-6-methylnicotinic acid. J. Mol. Struct., 2012, 1024, 104-109.

36 M.-L. Chen, Y.-R. Shi, Y.-C. Yang and Z.-H. Zhou, Acidic 1,3-propanediaminetetraacetato lanthanides with luminescent and catalytic ester hydrolysis properties. J. Solid State Chem., 2014, 219, 265-273.

37 Y. Qiongyan, Z. Xiuxia, L. Maosheng, C. Jianqiao, Z. Zhengyuan, Y. $\mathrm{Xia}$ and $\mathrm{C}$. Yuepeng, Syntheses, characterization, and luminescence of two lanthanide complexes $\left[\mathrm{Ln}_{2}(\text { acetate })_{6}\left(\mathrm{H}_{2} \mathrm{O}\right)_{4}\right] \mathrm{üE} 4 \mathrm{H}_{2} \mathrm{O}(\mathrm{Ln}=$ $\mathrm{Tb}(1), \operatorname{Sm}(2))$. J. Rare Earths, 2008, 26, 178-184.

38 P. Bag, S.K. Maji, P. Biswas, U. Flörke and K. Nag, Macrocyclic lanthanide(III) complexes of iminophenol Schiff bases and carboxylate anions: syntheses, structures and luminescence properties. Polyhedron, 2013, 52, 976-985.

39. M.C. Favas, D.L. Kepert, B.W. Skelton and A.H. White, Crystal structure of gadolinium(III) acetate tetrahydrate. Stereo-chemistry of the nine-co-ordinate $\left.\left[\mathrm{M}(\text { bidentate ligand })_{3} \text { (unidentate ligand }\right)_{3}\right]^{x \pm}$ system. J. Chem. Soc. Dalton Trans., 1980, 454-458.

40 Z.A. Taha, A.M. Ajlouni, A.K. Hijazi, N.A. Al-Rawashdeh, K.A. Al-Hassan, Y.A. Al-Haj, M.A. Ebqa'ai and A.Y. Altalafha, Synthesis and luminescent spectroscopy of lanthanide complexes with dimethylpyridine-2,6-dicarboxylate (dmpc). J. Lumin., 2015, 161, 229-238.

41 Poonam, R. Kumar, P. Boora, A. Khatkar, S.P. Khatkar and V.B. Taxak, Synthesis, photoluminescence and biological properties of terbium(III) complexes with hydroxyketone and nitrogen containing heterocyclic ligands. Spectrochim. Acta, Part A, 2016, 152, 304-310.

42 A.M. Ajlouni, Z.A. Taha, K.A. Al-Hassan and A.M.A. Anzeh, Synthesis, characterization, luminescence properties and antioxidant activity of Ln(III) complexes with a new aryl amide bridging ligand. J. Lumin., 2012, 132, 1357-1363.

43 M.C. Foti, C. Daquino and C. Geraci, Electron-transfer reaction of cinnamic acids and their methyl esters with the DPPH ${ }^{\bullet}$ radical in alcoholic solutions. J. Org. Chem., 2004, 69, 2309-2314. 


\section{Supplementary material to:}

M.N. Gueye, M. Dieng, I.E. Thiam, D. Lo, A.H. Barry, M. Gaye and P. Retailleau, Lanthanide(III) Complexes with Tridentate Schiff Base Ligand, Antioxidant Activity and X-Ray Crystal Structures of the $\mathrm{Nd}$ (III) and Sm(III) Complexes, S. Afr. J. Chem., 2017, 70, 8-15 
${ }^{1} \mathrm{H}$ NMR of HL ; HL =

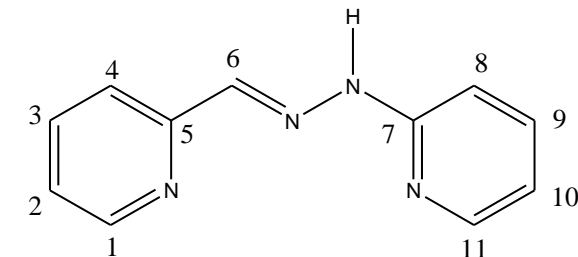

agm.10.fid

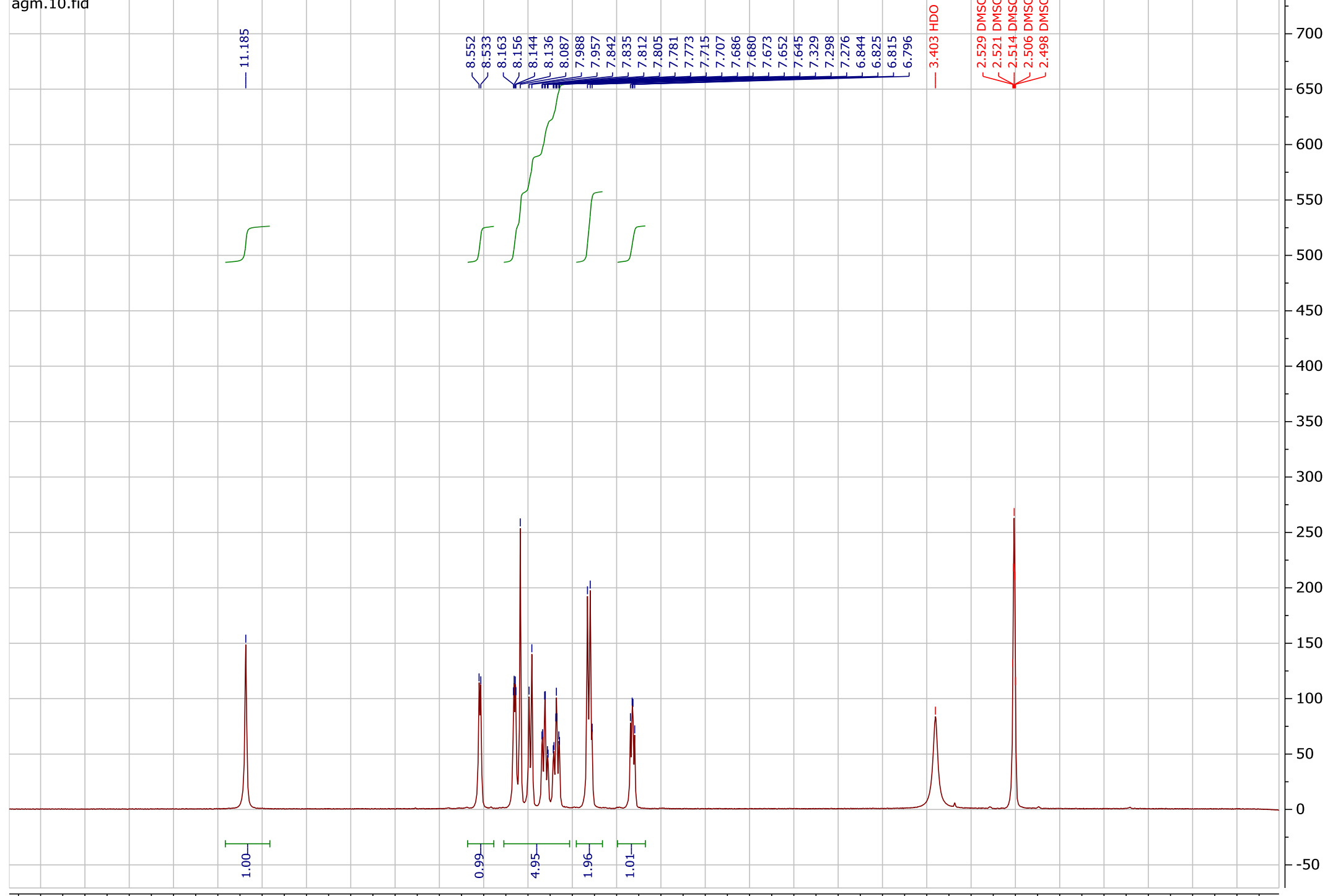

$\begin{array}{lllllllllllllllllllllllllllll}13.5 & 13.0 & 12.5 & 12.0 & 11.5 & 11.0 & 10.5 & 10.0 & 9.5 & 9.0 & 8.5 & 8.0 & 7.5 & 7.0 & 6.5 & 6.0 & 5.5 & 5.0 & 4.5 & 4.0 & 3.5 & 3.0 & 2.5 & 2.0 & 1.5 & 1.0 & 0.5 & 0.0\end{array}$ 
${ }^{13}$ C NMR of HL

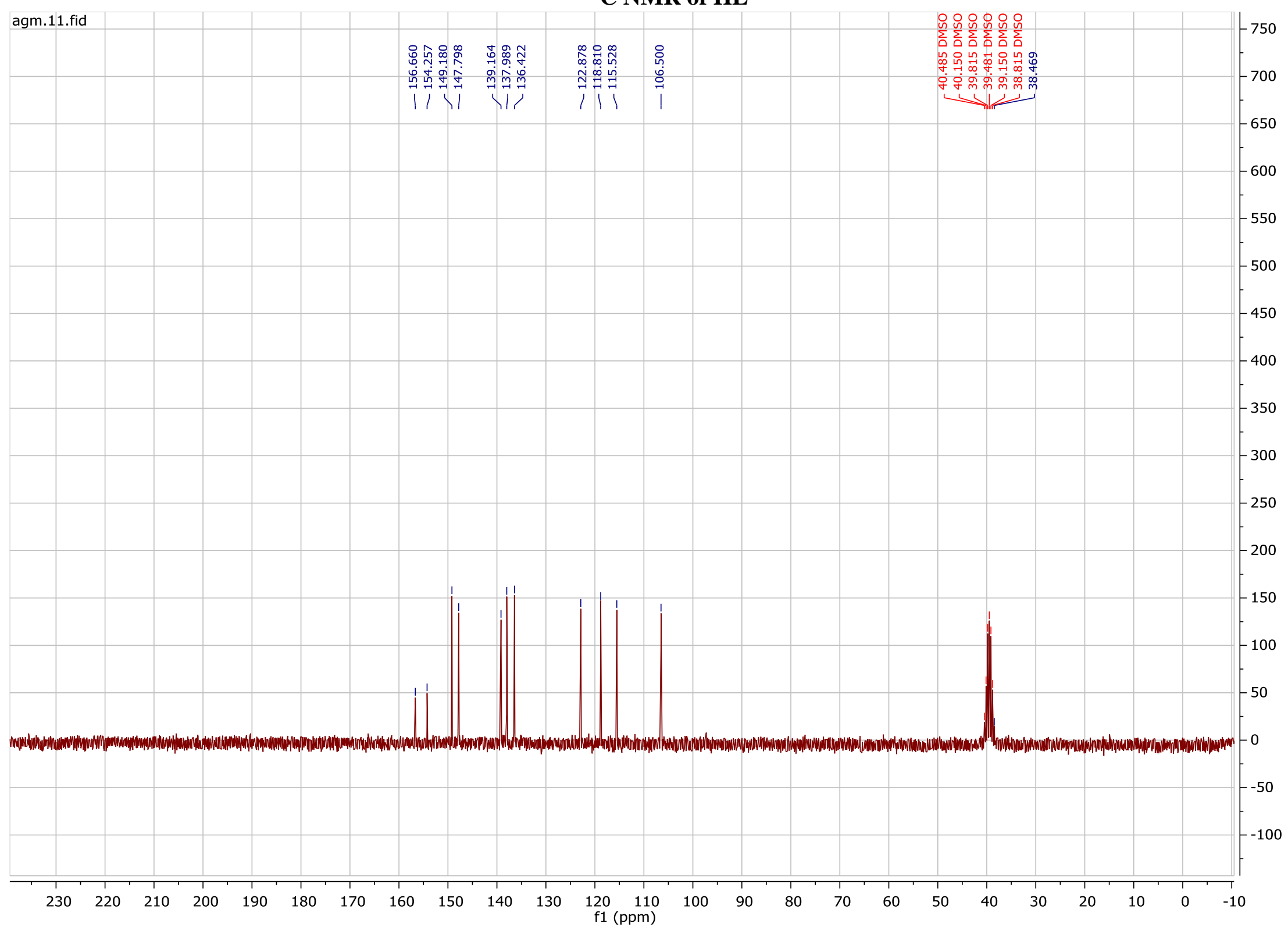


${ }^{1} \mathrm{H}$ NMR spectrum of $\left\{\left[\mathrm{Nd}(\mathrm{HL})\left(\eta^{2}-\mathrm{CH}_{3} \mathrm{COO}\right)\left(\mathrm{H}_{2} \mathrm{O}\right)_{2}\right]\left(\mu-\mathrm{CH}_{3} \mathrm{COO}\right)_{2}\left[\mathrm{Nd}(\mathrm{HL})\left(\eta^{2}-\mathrm{CH}_{3} \mathrm{COO}\right)\left(\mathrm{H}_{2} \mathrm{O}\right)_{2}\right]\right\} \cdot\left(\mathrm{NO}_{3}\right)_{2}$

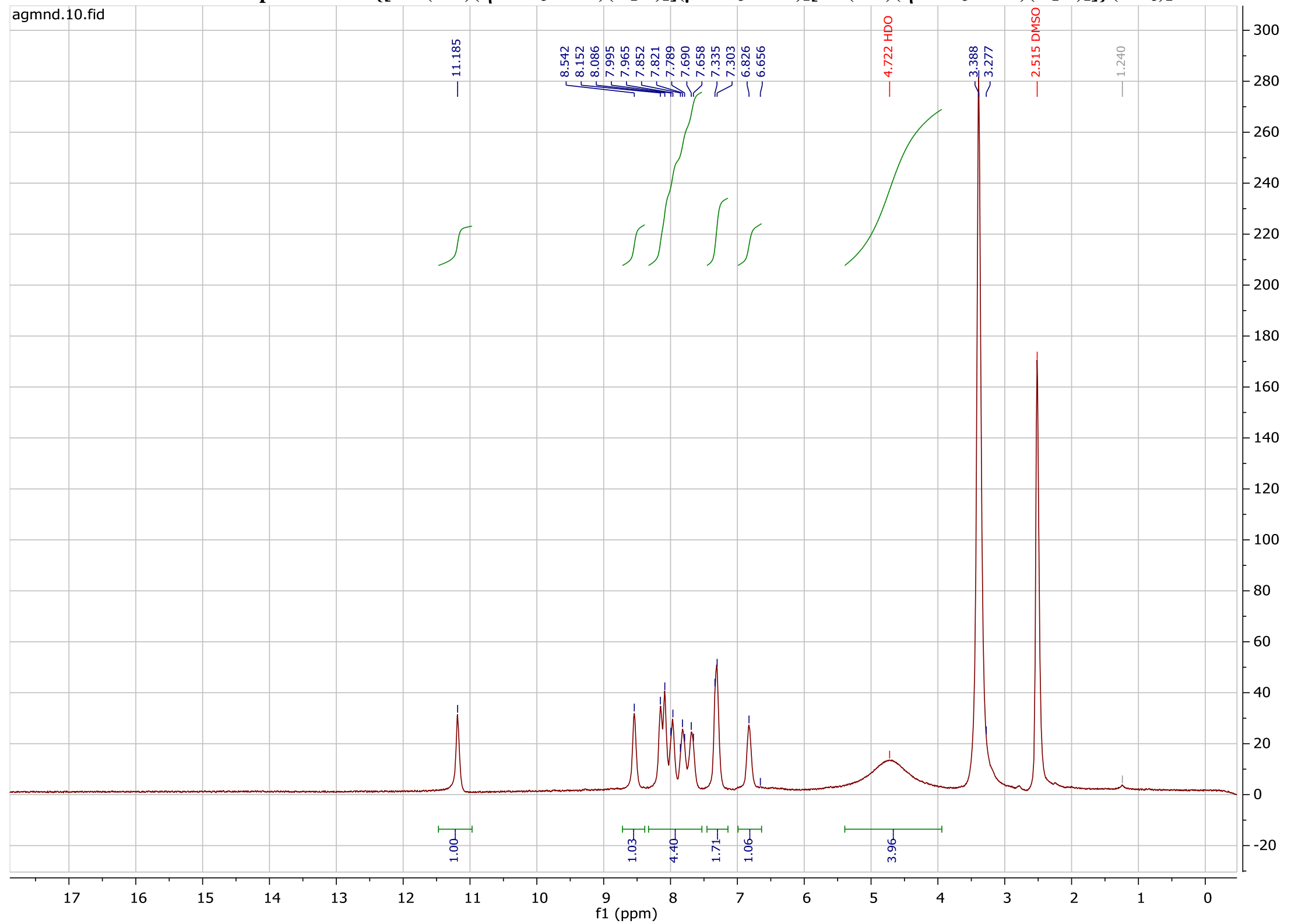


${ }^{13} \mathrm{C}$ NMR spectrum of $\left\{\left[\mathrm{Nd}(\mathrm{HL})\left(\eta^{2}-\mathrm{CH}_{3} \mathrm{COO}\right)\left(\mathrm{H}_{2} \mathrm{O}\right)_{2}\right]\left(\mu-\mathrm{CH}_{3} \mathrm{COO}\right)_{2}\left[\mathrm{Nd}(\mathrm{HL})\left(\eta^{2}-\mathrm{CH}_{3} \mathrm{COO}\right)\left(\mathrm{H}_{2} \mathrm{O}\right)_{2}\right]\right\} \cdot\left(\mathrm{NO}_{3}\right)_{2}$

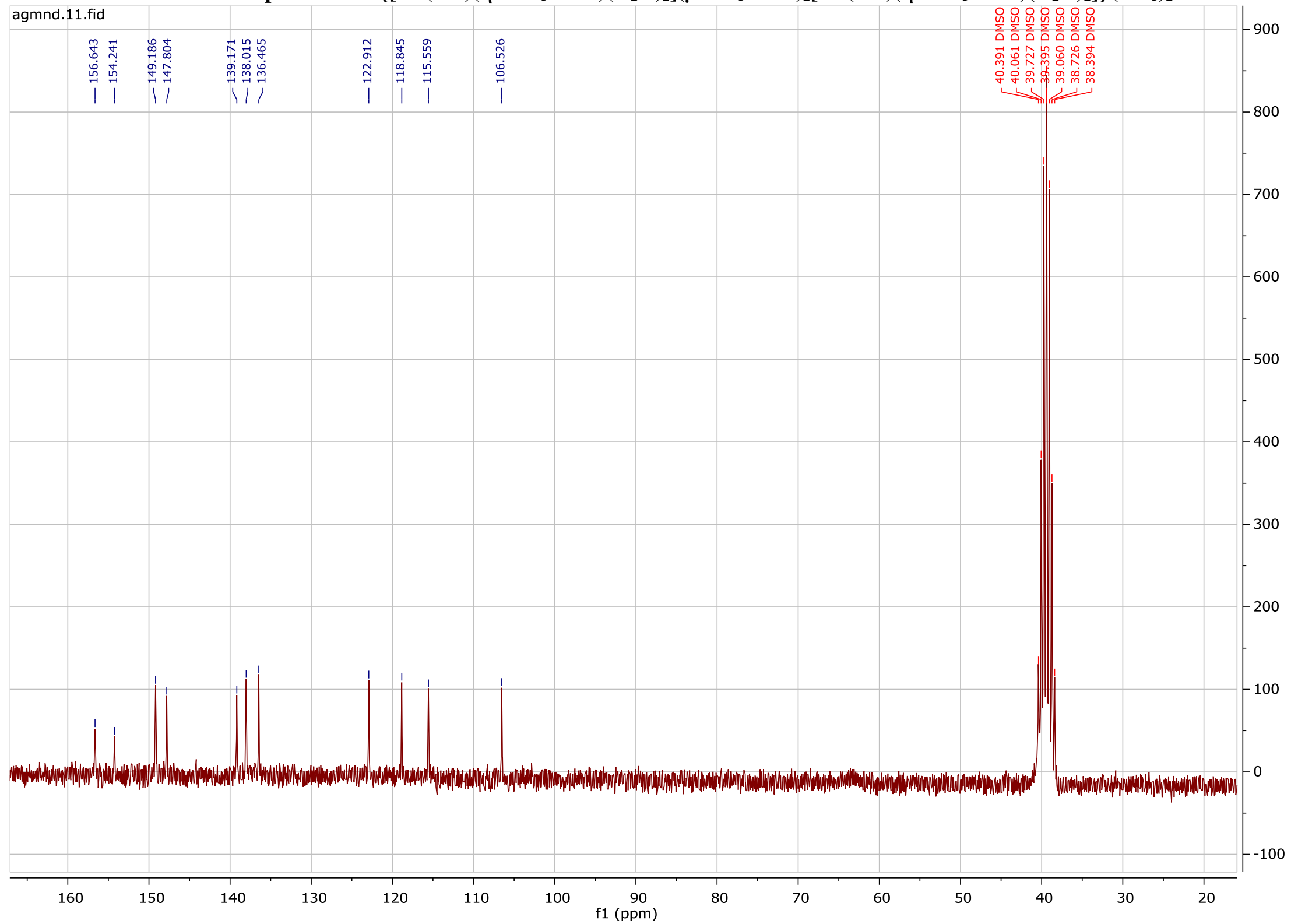


${ }^{1} \mathrm{H}$ NMR spectrum of $\left\{\left[\mathrm{Sm}(\mathrm{HL})\left(\eta^{2}-\mathrm{CH}_{3} \mathrm{COO}\right)\left(\mathrm{H}_{2} \mathrm{O}\right)_{2}\right]\left(\mu-\mathrm{CH}_{3} \mathrm{COO}\right)_{2}\left[\mathrm{Sm}(\mathrm{HL})\left(\eta^{2}-\mathrm{CH}_{3} \mathrm{COO}\right)\left(\mathrm{H}_{2} \mathrm{O}\right)_{2}\right]\right\} \cdot\left(\mathrm{NO}_{3}\right)_{2}$

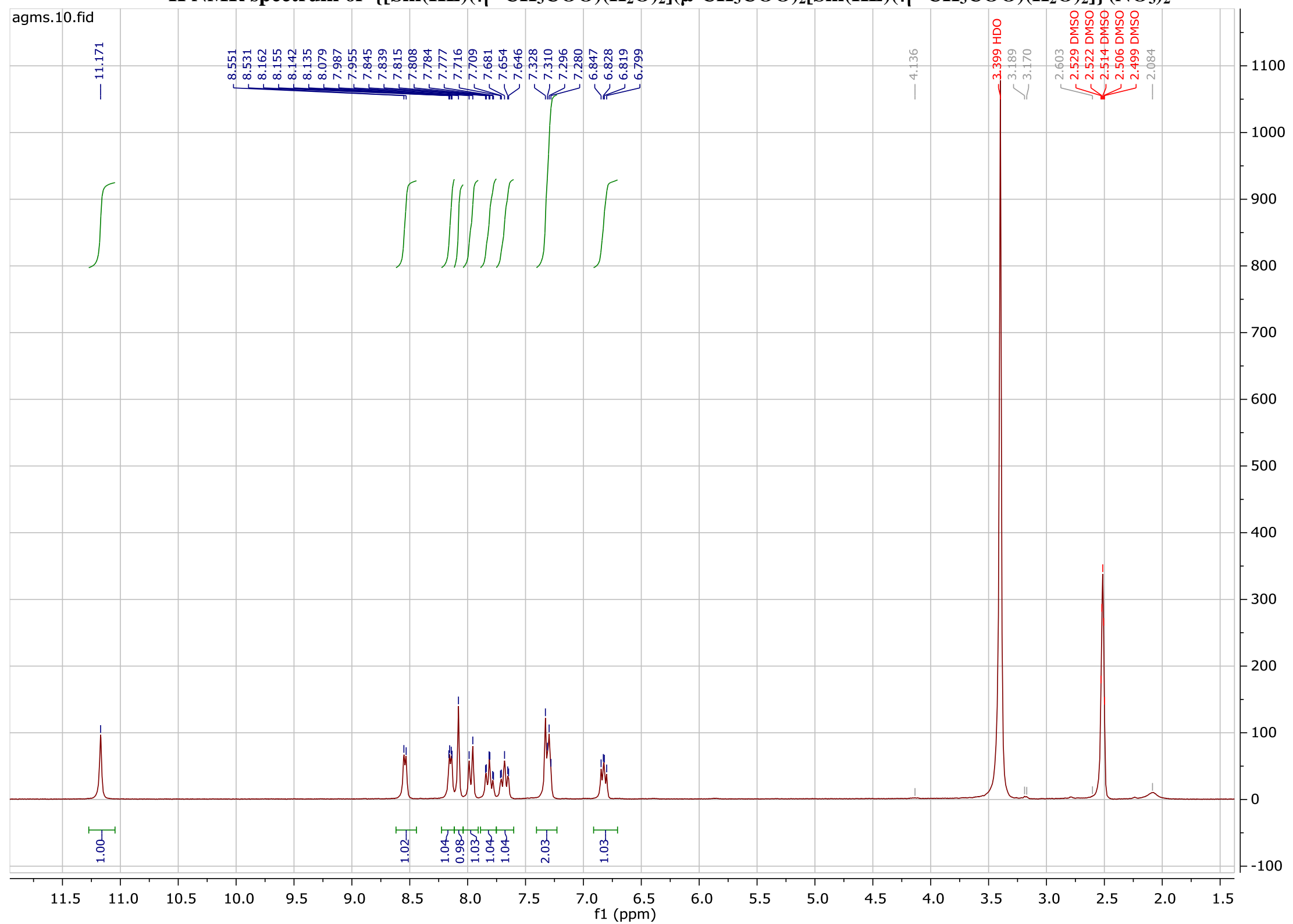


${ }^{1} \mathrm{H}$ NMR spectrum of $\left\{\left[\mathrm{Sm}(\mathrm{HL})\left(\eta^{2}-\mathrm{CH}_{3} \mathrm{COO}\right)\left(\mathrm{H}_{2} \mathrm{O}\right)_{2}\right]\left(\mu-\mathrm{CH}_{3} \mathrm{COO}\right)_{2}\left[\mathrm{Sm}(\mathrm{HL})\left(\eta^{2}-\mathrm{CH}_{3} \mathrm{COO}\right)\left(\mathrm{H}_{2} \mathrm{O}\right)_{2}\right]\right\} \cdot\left(\mathrm{NO}_{3}\right)_{2}$

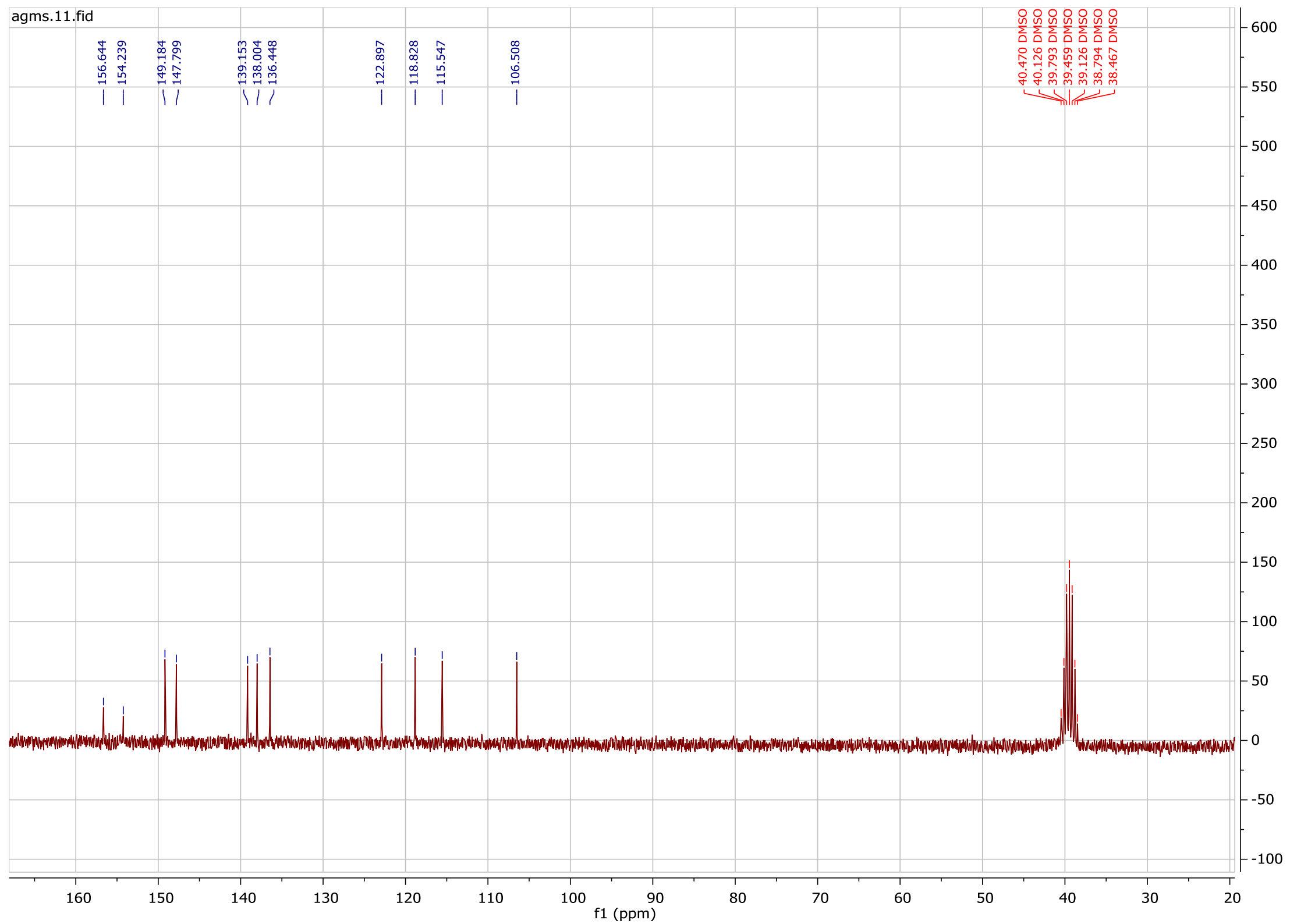

